\title{
PREDIKSI INTENSITAS CURAH HUJAN MENGGUNAKAN PRODUK NOWCASTING RTR DIBANDINGKAN DENGAN PRODUK ESTIMASI CURAH HUJAN SRI PADA KEJADIAN BANJIR DI PALEMBANG TANGGAL 12 - 13 NOVEMBER 2018
}

\author{
A RADAR-BASED RAIN RATE PREDICTION USING RTR NOWCASTING PRODUCT \\ COMPARED TO RAINFALL ESTIMATION PRODUCT OF SRI ON FLOOD EVENT \\ ACROSS PALEMBANG ON 12 - 13 NOVEMBER 2018
}

\author{
Anistia M Hidayat ${ }^{*}$, Diar Aofany ${ }^{1}$, Dinda R Arfianti ${ }^{1}$, Imma Redha Nugraheni ${ }^{1}$, Abdullah Ali ${ }^{3}$ \\ ${ }^{1}$ Sekolah Tinggi Meteorologi Klimatologi dan Geofisika, Indonesia \\ ${ }^{2}$ Subdivisi Pengelolaan Citra Radar, Badan Meteorologi Klimatologi dan Geofisika, Indonesia \\ *Email: anistia.malinda@gmail.com
}

\begin{abstract}
ABSTRAK
Palembang merupakan salah satu wilayah rawan terdampak banjir di Indonesia. Sebanyak 24 kasus banjir terjadi selama kurun waktu 2017-2018 dan memiliki kecenderungan untuk terus meningkat sepanjang tahun terhitung sejak 1972. Merujuk pada latar belakang tersebut, penelitian ini memanfaatkan produk Rain Tracking (RTR) untuk estimasi intensitas dan distribusi spasial curah hujan secara nowcasting. Laporan sinoptik Stasiun Meteorologi Sultan Mahmud Badaruddin II Palembang menunjukkan bahwa hujan yang sangat lebat terjadi dalam rentang waktu 14.00 - 18.00 UTC tanggal 12 November 2018. Analisis produk CAPPI dan SSA menunjukkan adanya pola sebaran awan konvektif dengan nilai reflectivity maksimum pada inti badai mencapai $58 \mathrm{dBZ}$ menyebar di atas lokasi penelitian pada pukul 16.10 UTC dan dikategorikan sebagai fase matang awan badai. Berdasarkan analisis MLVCUT (dBZ), nilai reflectivity maksimum pada fase matang awan badai adalah $48 \mathrm{dBZ}$ dengan tinggi puncak awan mencapai $6,15 \mathrm{~km}$. Pada waktu yang sama, analisis VVP menunjukkan adanya pola updraft kuat mencapai $9,25 \mathrm{~m} / \mathrm{s}$ dan downdraft yang kuat mencapai $-8,27 \mathrm{~m} / \mathrm{s}$. Hasil prediksi dengan produk Rain Tracking (RTR) menunjukkan nilai intensitas curah hujan yang cenderung lebih mendekati hasil pengukuran curah hujan sebenarnya menggunakan ARG, dengan selisih nilai absolut berkisar antara 1,24 $14,76 \mathrm{~mm} / \mathrm{jam}$. Sementara selisih nilai absolut intensitas curah hujan antara produk SRI dan ARG dalam periode waktu yang sama menunjukkan penyimpangan yang lebih besar, yaitu $0,92-24,53 \mathrm{~mm} / \mathrm{jam}$.
\end{abstract}

Kata kunci: banjir, hujan lebat, nowcasting, RTR, SRI

\section{ABSTRACT}

Palembang is one of flood prone-areas in Indonesia. Twenty-four cases of flood have recorded during 20172018 and have tendency to increase throughout the year starting from 1972. Regarding to this issue, we consider a novel approach on utilizing Rain Tracking (RTR) product to estimate the intensity and distribution of rainfall fields in near-future (nowcasting). The synoptic report of Meteorological Station Sultan Mahmud Badaruddin II Palembang showed that torrential rain occured in November 12th 2019, around 14.00-18.00 UTC. Analysis of CAPPI and SSA products shows a pattern of convective cloud distribution with maximum reflectivity in its storm core reach up to $58 \mathrm{dBZ}$, spread over research sites at 16.10 UTC and considered as mature stage. MLVCUT (dBZ) analysis on the mature stage shows that the maximum reflectivity value is $48 \mathrm{dBZ}$ with peak reach up to $6,15 \mathrm{~km}$. While, analysis on the VVP products shows strong updraft pattern with maximum velocity of $9,25 \mathrm{~m} / \mathrm{s}$ and strong downdraft reach up to $-8,27 \mathrm{~m} / \mathrm{s}$. Prediction of the intensity and rainfall fields distribution using $R T R$ product shows a good approximation compared to the observed rainfall intensity measured by ARG, with absolute deviation values ranges between 1.24 - $14.76 \mathrm{~mm} / \mathrm{hour}$. While, the difference in rainfall intensity between SRI and ARG products relatively has larger deviation, ranges between $0.92-24.53 \mathrm{~mm} / \mathrm{hour}$.

Keywords: flood, torrential rain, nowcasting, RTR, SRI 


\section{PENDAHULUAN}

Fourth Assessment Report of the International Panel on Climate Change (IPCC AR4) menjelaskan bahwa terdapat potensi peningkatan presipitasi di wilayah Indonesia di bawah skenario kondisi perubahan iklim global (IPCC, 2017). Selama rentang waktu 1970 2011, terjadi 3.980 kejadian banjir di Indonesia yang telah merusak setidaknya 1,1 juta hektar areal persawahan dan $65.000 \mathrm{~km}$ jalan (Lassa, 2012).

Laporan Badan Nasional Penanggulangan Bencana (BNPB) menunjukkan adanya kecenderungan peningkatan kejadian banjir di wilayah Sumatra Selatan terhitung sejak tahun 1972. Pada tahun 2017, jumlah kejadian banjir sebanyak 24 kasus. Jumlah kejadian banjir meningkat pada tahun 2018, yaitu sebesar 28 kasus. Bukan hanya menyebabkan kerusakan pada rumah-rumah, banjir di wilayah Sumatra Selatan tahun 2018 juga menyebabkan kerusakan pada 3 unit fasilitas kesehatan, 3 unit fasilitas peribadatan, dan 7 unit fasilitas pendidikan.

Berdasarkan laporan sinoptik Stasiun Meteorologi Sultan Mahmud Badaruddin II, terjadi hujan ekstrem pada malam hari tanggal 12 November 2018 hingga dini hari tanggal 13 November 2018. Laporan tersebut juga menunjukkan diamatinya badai guntur diiringi hujan sangat lebat pada pukul 15.00 UTC dan bertahan hingga beberapa saat sebelum pukul 18.00 UTC. Berdasarkan hasil survei Dinas Pekerjaan Umum dan Penataan Ruang (PUPR) Kota Palembang setidaknya ada 19 titik banjir terjadi akibat hujan deras yang melanda (Triansyah, 2018). Berpijak pada penjelasan tersebut, urgensi perancangan sistem peringatan dini banjir semakin meningkat seiring dengan semakin banyaknya wilayah yang rentan terdampak banjir di Indonesia, termasuk di Palembang. Seiring dengan perkembangan teknologi penginderaan jarak jauh, pengukuran curah hujan dengan menggunakan radar cuaca memungkinkan pengamat menjangkau area yang lebih luas dengan resolusi spasial dan temporal yang lebih rapat. Perata-rataan curah hujan menggunakan radar data memberikan hasil yang lebih baik dalam hal pengamatan curah hujan (James dkk., 1993).

Beberapa penelitian terkait kejadian banjir dengan menggunakan radar cuaca telah banyak dilakukan sebelumnya. Penelitian Paski, dkk. Pada tahun 2016 menggunakan beberapa produk radar, diantaranya Constant Altitude
Plan Position Indicator (CAPPI), Precipitation Accumulation (PAC), Horizontal Wind (HWIND), Column Maximum (CMAX), dan Vertical Cut (VCUT) untuk menganalisis dinamika atmosfer pada saat hujan ekstrem yang menyebabkan banjir di Kota Bengkulu tahun 2014. Berbeda dengan Paski dkk., pada tahun 2016 penelitian Permana dan Fachrurrozi menggunakan data Maximum Display (MAX) dibanding CMAX untuk menganalisis reflectivity awan pada kejadian banjir di Kediri, Nusa Tenggara Barat(Permana dan Fachrurrozi, 2016). Ariyanti dkk., 2016 menambahkan analisis produk Echo-Top Height (ETOP) dan EBASE untuk mengidentifikasi awan badai konvektif pada saat kejadian hujan lebat yang mengakibatkan banjir di Jakarta tanggal 20 April 2016. Secara umum, penelitian terkait banjir masih sebatas menganalisis intensitas curah hujan berdasarkan produk hidrologi radar cuaca dan karakteristik awan penyebab hujan lebat pada saat kejadian banjir. Oleh karena itu, penulis tertarik untuk menganalisis kejadian banjir di Palembang bukan hanya ditinjau dari analisis jenis awan penyebab hujan lebat dan intensitas curah hujannya saja, tetapi juga memprakirakan intensitas dan pergerakan medan curah hujan di wilayah penelitian dengan menggunakan produk Rain Tracking (RTR).

\section{DATA DAN METODE}

Data yang digunakan dalam penelitian ini adalah data pengamatan sinoptik, data curah hujan yang diamati menggunakan Automatic Rain Gauge (ARG), dan data radar cuaca Gematronik Stasiun Meteorologi Sultan Mahmud Badaruddin II tanggal 12 - 13 November 2018. Ketinggian lokasi instalasi radar cuaca adalah $16 \mathrm{~m}$ dari permukaan laut, sementara ketinggian Stasiun Meteorologi Sultan Mahmud Badaruddin II dari permukaan laut adalah $15 \mathrm{~m}$. Informasi tersebut penting diketahui sebagai referensi untuk mengatur nilai masukan faktor ketinggian pada beberapa produk radar cuaca. Posisi koordinat radar cuaca adalah $2^{\circ} 55^{\prime} 1^{\prime \prime}$ LS dan $104^{\circ} 42^{\prime} 10^{\prime \prime} \mathrm{BT}$, sementara pengamatan curah hujan dilakukan oleh Stasiun Meteorologi Sultan Mahmud Badaruddin II Palembang yang terletak pada koordinat $2^{\circ} 53^{\prime} 48^{\prime \prime}$ LS dan $104^{\circ} 42^{\prime}$ BT dan kemudian ditentukan sebagai fokus lokasi penelitian.

Penentuan relasi $Z-R$ pada penelitian ini menggunakan algoritma hubungan Z-R 
Rosenfeld Tropical (RT) karena fokus lokasi penelitian bersesuaian dengan latar belakang lokasi penelitian yang dilakukan oleh Rosenfeld, et al., yaitu daerah tropis (Rosenfeld dkk., 1993). Merujuk pada penelitian Rosenfeld, et al., hubungan antara intensitas curah hujan $(R)$ dengan nilai reflectivity $\operatorname{radar}(Z)$ secara matematis diformulasikan sebagai berikut (Rosenfeld dkk., 1993):

$$
Z=a R^{b}
$$

dimana $Z$ merupakan faktor reflectivity radar $\left(\mathrm{mm}^{6} / \mathrm{m}^{3}\right)$ dan nilai $a$ dan $b$ berturut-turut didasarkan pada persamaan Rosenfeld Tropical, yaitu 250 dan 1,2 .

Analisis pertama kali dilakukan dengan mengidentifikasi kondisi atmosfer pada saat sebelum sampai sesudah kejadian hujan lebat berdasarkan laporan sinoptik Stasiun Meteorologi Sultan Mahmud Badaruddin II Palembang. Selanjutnya, produk CAPPI (dBZ) diolah untuk mengetahui sebaran awan pada ketinggian yang tetap dari permukaan yang diatur menjadi $0,7 \mathrm{~km}$. Produk tersebut kemudian di-overlay dengan produk Storm Structure Analysis (SSA) untuk mendapatkan gambaran struktur awan badai dalam jangkauan observasi radar. Produk MLVCUT (dBZ) diolah untuk mengetahui sebaran nilai reflectivity pada penampang vertikal awan badai. Analisis mekanisme pergerakan vertikal massa udara dilakukan dengan menggunakan produk Volume Velocity Processing (VVP). Produk hidrologi yang digunakan dalam penelitian ini adalah produk SRI dengan algoritma Rosenfeld Tropical. Produk SRI tersebut kemudian dibandingkan dengan produk RTR dan data curah hujan ARG Stasiun Meteorologi Sultan Mahmud Badaruddin II dengan maksud untuk mengetahui performa produk RTR dalam memprakirakan intensitas dan sebaran spasial curah hujan.

Jenis awan dalam penelitian ini ditentukan berdasarkan metode yang dijelaskan oleh Gamache dan Houze (Gamache dan Houze, 1982) serta (Widomurti, 2017). Berdasarkan nilai reflectivity. Pemisahan jenis awan berdasarkan fluktuasi rain rate didasarkan pada penelitian Nzeuko dan Seuvageot (Nzeukou dan Sauvageot, 2004). Awan jenis stratiform ditentukan berdasarkan nilai rain rate yang cenderung seragam kurang dari $10 \mathrm{~mm} / \mathrm{jam}$ dan nilai reflectivity kurang dari $38 \mathrm{dBZ}$. Awan badai konvektif ditentukan berdasarkan nilai rain rate yang lebih dari sama dengan 10 $\mathrm{mm} / \mathrm{jam}$ dan nilai reflectivity lebih dari sama dengan 38 dBZ. Rincian dari penjelasan tersebut dirangkum dalam Tabel 1 dan 2 berikut:

Tabel 1. Penentuan VIP Level Awan Stratiform (Widomurti, 2017)

\begin{tabular}{|c|c|c|c|}
\hline \multirow{2}{*}{ VIP Level } & \multicolumn{3}{|c|}{ Stratiform } \\
\cline { 2 - 4 } & \multirow{2}{*}{ dBZ } & \multicolumn{2}{|c|}{ Curah Hujan (mm/jam) } \\
\cline { 3 - 4 } & & Radar & Observasi \\
\hline Ringan & $13-$ & $0,1-1,38$ & $0,1-5,0$ \\
& 31 & & $5,0-10,0$ \\
\hline Sedang & $31-$ & $1,38-6,92$ & \\
& 37 & & \\
\hline
\end{tabular}

Tabel 2. Penentuan VIP Level Awan Konvektif (Widomurti, 2017)

\begin{tabular}{|c|c|c|c|}
\hline \multirow{2}{*}{ VIP Level } & \multicolumn{3}{|c|}{ Konvektif } \\
\cline { 2 - 4 } & \multirow{2}{*}{ dBZ } & \multicolumn{2}{|c|}{ Curah Hujan (mm/jam) } \\
\cline { 3 - 4 } & & Radar & Observasi \\
\hline Lebat & $38-$ & $6,92-18,49$ & $10-20$ \\
& 49 & & $>20$ \\
\hline $\begin{array}{c}\text { Sangat } \\
\text { Lebat }\end{array}$ & $>49$ & $>18,49$ & \\
\hline
\end{tabular}

\section{HASIL DAN PEMBAHASAN}

\subsection{Kondisi Cuaca Berdasarkan Laporan Sinoptik}

Wardoyo menjelaskan bahwa untuk kasus banjir dan longsor, perlu diperhatikan akumulasi hujan dalam rentang waktu 3 hari hingga seminggu (Wardoyo, 2017). Hal tersebut dikarenakan pada beberapa kasus, intensitas curah hujan yang diamati pada produk radar pada saat kejadian tidak menunjukkan adanya indikasi hujan lebat, namun dalam praktiknya telah terjadi banjir di wilayah tersebut. Setelah dilakukan pengolahan data beberapa hari sebelumnya, ditemukan bahwa terjadi hujan sangat lebat dengan intensitas yang bervariasi pada periode waktu 
sebelumnya. Merujuk pada penjelasan tersebut, peneliti mengumpulkan data curah hujan pada 3 hari sebelum dan setelah kejadian banjir tanggal
12 - 13 November 2018 yang ditampilkan pada Tabel 1 berikut:

Tabel 3. Akumulasi Curah Hujan Berdasarkan Laporan Sinoptik

\begin{tabular}{ccc}
\hline No & Tanggal & Akumulasi Curah Hujan (mm) \\
\hline 1 & 10 November 2018 & 1 \\
2 & 11 November 2018 & 21 \\
3 & 12 November 2018 & 2 \\
4 & 13 November 2018 & 115,2 \\
5 & 14 November 2018 & TTU \\
6 & 15 November 2018 & 0 \\
7 & 16 November 2018 & 1 \\
\hline
\end{tabular}

Tabel 4. Akumulasi Curah Hujan Berdasarkan Laporan Sinoptik Tanggal 12 November 2018

\begin{tabular}{ccc}
$\begin{array}{c}\text { Waktu } \\
\text { (UTC) }\end{array}$ & $\begin{array}{c}\text { Akumulasi Curah Hujan } \\
(\mathbf{m m})\end{array}$ & $\begin{array}{c}\text { Jenis Awan } \\
\text { (Awan Rendah/Awan } \\
\text { Menengah/Awan Tinggi) }\end{array}$ \\
\hline 15.00 & 45 & Kumulonimbus/Altostratus/- \\
18.00 & 54,6 & Stratus/Altostratus/- \\
21.00 & 13 & Stratus/Altostratus/- \\
\hline
\end{tabular}

Berdasarkan Tabel 3 dan 4, dapat diketahui bahwa kejadian banjir pada tanggal 13 November 2018 disebabkan oleh hujan sangat lebat pada tanggal 12 November 2018, dengan akumulasi curah hujan mencapai 115,2 mm. Berdasarkan laporan sinoptik, awan badai konvektif mulai diamati dan dilaporkan pada pukul 10.00 UTC. Pada pukul 11.00 UTC, dilaporkan terjadi hujan dengan intensitas ringan dan tidak kontinyu. Pengukuran curah hujan pada pukul 12.00 UTC menunjukkan curah hujan yang diamati adalah kurang dari $0,1 \mathrm{~mm}$. Selang beberapa jam kemudian, hujan dengan intensitas ringan hingga sedang disertai badai guntur terjadi, dengan akumulasi curah hujan yang diukur pada pukul 15.00 UTC mencapai $45 \mathrm{~mm}$. Hujan disertai badai guntur tersebut terus berlangsung hingga beberapa jam kemudian dan pada saat pukul 18.00 UTC, akumulasi curah hujan dilaporkan sebesar 54,6 $\mathrm{mm}$. Akumulasi curah hujan selama 6 jam terakhir menunjukkan nilai 99,6 $\mathrm{mm}$. Selanjutnya hujan dengan intensitas ringan dari jenis awan stratus terjadi secara kontinyu dan dilaporkan sebesar $15 \mathrm{~mm}$ pada pukul 21.00 UTC. Merujuk pada penjelasan tersebut, penelitian ini akan terfokus untuk menganalisis kondisi atmosfer, khususnya pada pukul 14.00 18.00 UTC, dimana kejadian hujan akibat awan konvektif memiliki kontribusi nilai paling besar dalam total curah hujan yang diamati.

\subsection{Analisis Reflectivity Awan Badai Konvektif}

Analisis reflectivity pada sebaran awan badai dilakukan dengan menggunakan produk CAPPI yang di-overlay dengan produk SSA, seperti yang ditunjukkan oleh Gambar 1. Pengamatan sebaran awan dengan menggunakan CAPPI dan SSA menunjukkan hasil yang sesuai dengan kondisi perawanan yang dilaporkan pada laporan sinoptik Stasiun Meteorologi Sultan Mahmud Badaruddin II. Penentuan jenis awan didasarkan pada penelitian Gamache dan Houze yang menjelaskan bahwa awan konvektif memiliki nilai reflectivity $\geq 38 \mathrm{dBZ}$ (Gamache dan Houze, 1982), berorientasi secara vertikal, namun berbentuk landai atau miring. Penelitian Widomurti di Bima menunjukkan bahwa awan konvektif dengan reflectivity sekitar $38-49$ dBZ memiliki potensi terjadinya hujan lebat (Tabel 2) (Widomurti, 2017). Apabila nilai reflectivity berada dalam rentang $13-31 \mathrm{dBZ}$, maka awan tersebut dikategorikan sebagai awan stratiform yang berpotensi menyebabkan hujan dengan intensitas ringan (Tabel 1). Nilai reflectivity 31 - $37 \mathrm{dBZ}$ juga dikategorikan sebagai kelompok klaster awan stratiform yang berpotensi menyebabkan hujan dengan intensitas sedang.

Analisis yang didasarkan pada Gambar 1 menunjukkan bahwa pada pukul 13.20 UTC, nilai reflectivity maksimum pada inti awan badai (storm core) mencapai $53 \mathrm{dBZ}$ dengan luas $19 \mathrm{~km}^{2}$. Sementara nilai reflectivity 
maksimum pada cakupan awan badai (storm) mencapai $57 \mathrm{dBZ}$ dan meluas hingga menutupi wilayah penelitian, radar, dan sekitarnya pada pukul 16.10 UTC. Pada waktu tersebut, diamati adanya tiga inti awan badai dalam sebaran awan yang melingkupi wilayah penelitian dan sekitarnya dengan nilai reflectivity maksimum mencapai $56-58 \mathrm{dBZ}$. Cakupan awan badai tersebut mencapai luas maksimumnya pada pukul 16.10 UTC, yaitu $736 \mathrm{~km}^{2}$. Pada pukul 17.20 UTC, tidak lagi diamati adanya cakupan awan badai di atas lokasi penelitian dan sekitarnya. Sebaran nilai reflectivity maksimum pada wilayah penelitian dan sekitarnya berada pada rentang nilai $10-33 \mathrm{dBZ}$. Merujuk pada penelitian yang dilakukan oleh Gamache dan Houze dan Widomurti, sebaran awan pada pukul 13.20 UTC dan 16.10 UTC dikategorikan sebagai awan konvektif dan berpotensi menghasilkan hujan dengan intensitas sangat lebat. Sementara sebaran awan yang diamati pada pukul 17.20 UTC menunjukkan awanawan dengan jenis stratiform yang berpotensi menyebabkan hujan dengan intensitas ringan hingga sedang.
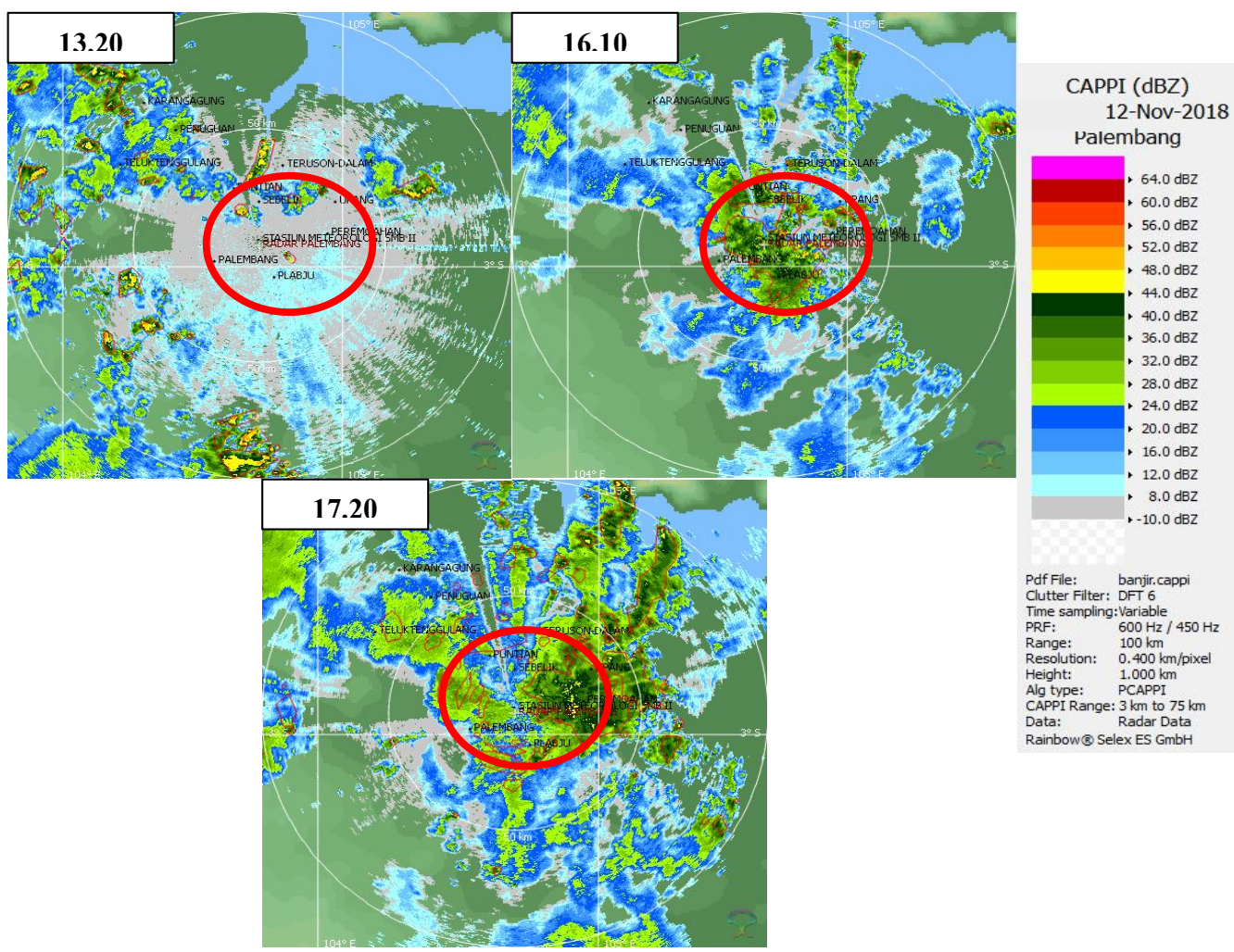

Gambar 1. Sebaran reflectivity pada produk CAPPI dengan overlay produk SSA pada ketinggian 700 meter. Luasan wilayah awan yang dibatasi dengan garis kuning pada produk SSA menunjukkan inti dari awan badai konvektif, sementara luasan yang dibatasi dengan garis merah munjukkan luasan awan badai. Lingkaran merah dengan garis putus-putus menunjukkan pola sebaran awan pada lokasi penelitian dan sekitarnya.

\subsection{Analisis Penampang Vertikal Awan Badai}

Analisis penampang vertikal awan badai konvektif dilakukan dengan menggunakan produk Multiple-Line Cut (MLVCUT). Analisis MLVCUT (dBZ) pada struktur awan badai dapat menunjukkan fase pertumbuhan sistem sel awan hujan (Wardoyo, 2017). Analisis MLVCUT dimulai dari wilayah bebas awan di arah tenggara dari posisi radar, memanjang melewati dekat posisi radar cuaca dan lokasi penelitian di Stasiun Meteorologi Sultan
Mahmud Badaruddin II, dan berakhir pada wilayah bebas awan di sisi barat laut radar cuaca. Lintasan pada produk MLVCUT secara visual ditunjukkan pada Gambar 2a.

Sementara Gambar 2b, 2c, dan 2d menunjukkan penampang vertikal struktur awan badai konvektif beserta dengan informasi terkait dengan sebaran nilai reflectivity. Analisis struktur vertikal pada produk reflectivity menunjukkan bahwa awan badai konvektif mulai tampak jelas sekitar pukul 13.20 UTC dengan nilai reflectivity maksimum 
59,5 dBZ dan tinggi puncak awan mencapai $4,67 \mathrm{~km}$ dari permukaan. Nilai reflectivity maksimum tersebut terletak pada ketinggian rendah sekitar $1-4 \mathrm{~km}$. Szoke dan Zipster menyatakan bahwa kondisi tersebut dapat terjadi karena adanya tetes - tetes air terkonsentrasi pada lapisan rendah tidak mampu dinaikkan oleh updraft yang lemah (Szoke dkk., 1985). Diperkirakan ketinggian awan yang tumbuh tepat di atas lokasi penelitian dan radar melebihi ketinggian tersebut, namun karena keterbatasan pemindaian radar terdapat cone of silence, kondisi dimana antena radar tidak mampu mendongak lebih tinggi.

Analisis kecepatan vertikal pada Gambar 3 menunjukkan bahwa terdapat dominansi kecepatan vertikal yang bernilai positif pada pukul 13.20 UTC. Kollias, et al. menjelaskan bahwa nilai kecepatan vertikal positif berkorelasi dengan adanya mekanisme updraft dalam sebuah sel badai (Kollias dkk., 2001). Analisis produk VVP pada pukul 13.20 UTC menunjukkan adanya mekanisme updraft yang lebih dominan dengan nilai kecepatan maksimumnya mencapai $8,44 \mathrm{~m} / \mathrm{s}$. Kondisi tersebut mengindikasikan adanya mekanisme updraft yang lebih dominan dalam struktur vertikal awan badai sehingga awan badai tersebut dikategorikan berada dalam fase tumbuh (towering cumulus stage). Karakteristik ini juga dijelaskan oleh Byers dan Hull, 1949 serta Byers dan Braham, 1949 yang menyatakan bahwa pada fase awal pertumbuhan sel badai, terdapat arus masuk atau konvergensi horizontal pada lapisan permukaan hingga pada seluruh lapisan ketinggian yang dicapai oleh awan.

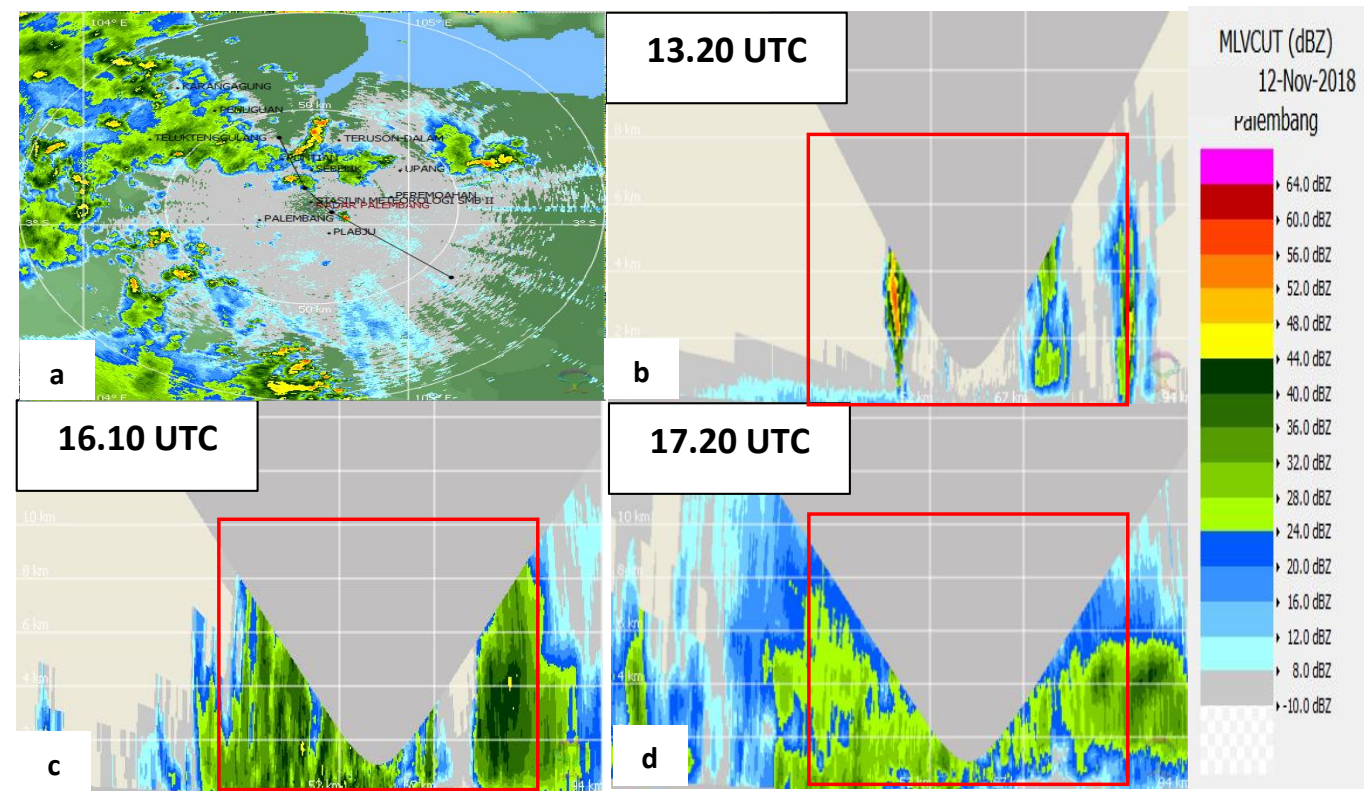

Gambar 2. a) Lintasan garis MLVCUT terdiri dari 4 titik koordinat yang memberikan gambaran penampang vertikal awan sepanjang lintasan yang dilalui, b,c,d) Penampang vertikal awan badai kumulonimbus ditinjau dari nilai reflectivity. Kotak merah menunjukkan lokasi penelitian dan wilayah sekitar radar cuaca, dimana diamati adanya cone of silence.

Pada pukul 16.10 UTC, awan badai konvektif memasuki tahap matang, dimana mekanisme updraft dan downdraft-nya seimbang dan memiliki nilai reflectivity paling tinggi. Byers dan Braham menjelaskan bahwa pada saat awan badai konvektif memasuki fase matang, maka terdapat mekanisme updraft dan downdraft yang kuat dengan arus keluar di permukaan (Byers dan Braham, 1949).

Analisis produk VVP menunjukkan mekanisme updraft dengan kecepatan mencapai $9,25 \mathrm{~m} / \mathrm{s}$, sementara nilai kecepatan negatif yang mengindikasikan terjadinya downdraft mencapai $-8,27 \mathrm{~m} / \mathrm{s}$. Nilai kecepatan negatif berkorelasi dengan reflectivity rendah yang mungkin dihasilkan dari penguapan tetesan awan saat udara turun dalam downdraft di sepanjang tepi awan (Kollias dkk., 2001). Awan badai yang diamati pada pukul 16.10 UTC memiliki nilai reflectivity maksimum $48 \mathrm{dBZ}$ dengan tinggi puncak awan mencapai $6,15 \mathrm{~km}$ dari permukaan tanah.

Pada pukul 17.20 UTC, awan badai mulai memasuki fase disipasi. Hal tersebut dapat 
diidentifikasi melalui tidak diamatinya sebaran awan badai berdasarkan produk CAPPI dan SSA. Selain itu, mekanisme downdraft relatif lebih dominan dibandingkan updraft namun intensitas keduanya lemah. Pada pukul 17.20 UTC, mekanisme downdraft cenderung dominan dengan kecepatan berada pada rentang nilai $-0,38$ sampai $-6,17 \mathrm{~m} / \mathrm{s}$. Byers dan Braham menjelaskan bahwa pada saat awan badai konvektif memasuki fase disipasi, ${ }^{16}$ maka akan diamati adanya updraft dan downdraft yang lemah. Awan tersebut memiliki nilai reflectivity maksimum yang relatif lebih rendah dibanding fase tumbuh atau matang, yaitu sekitar 37,5 dBZ dengan tinggi puncak awan yang lebih rendah sekitar $4 \mathrm{~km}$. Secara umum, produk reflectivity pada MLVCUT dan VVP mampu menunjukkan fase pertumbuhan hingga disipasi awan badai sehingga dapat digunakan untuk mengidentifikasi sel awan badai penyebab hujan di wilayah penelitian.
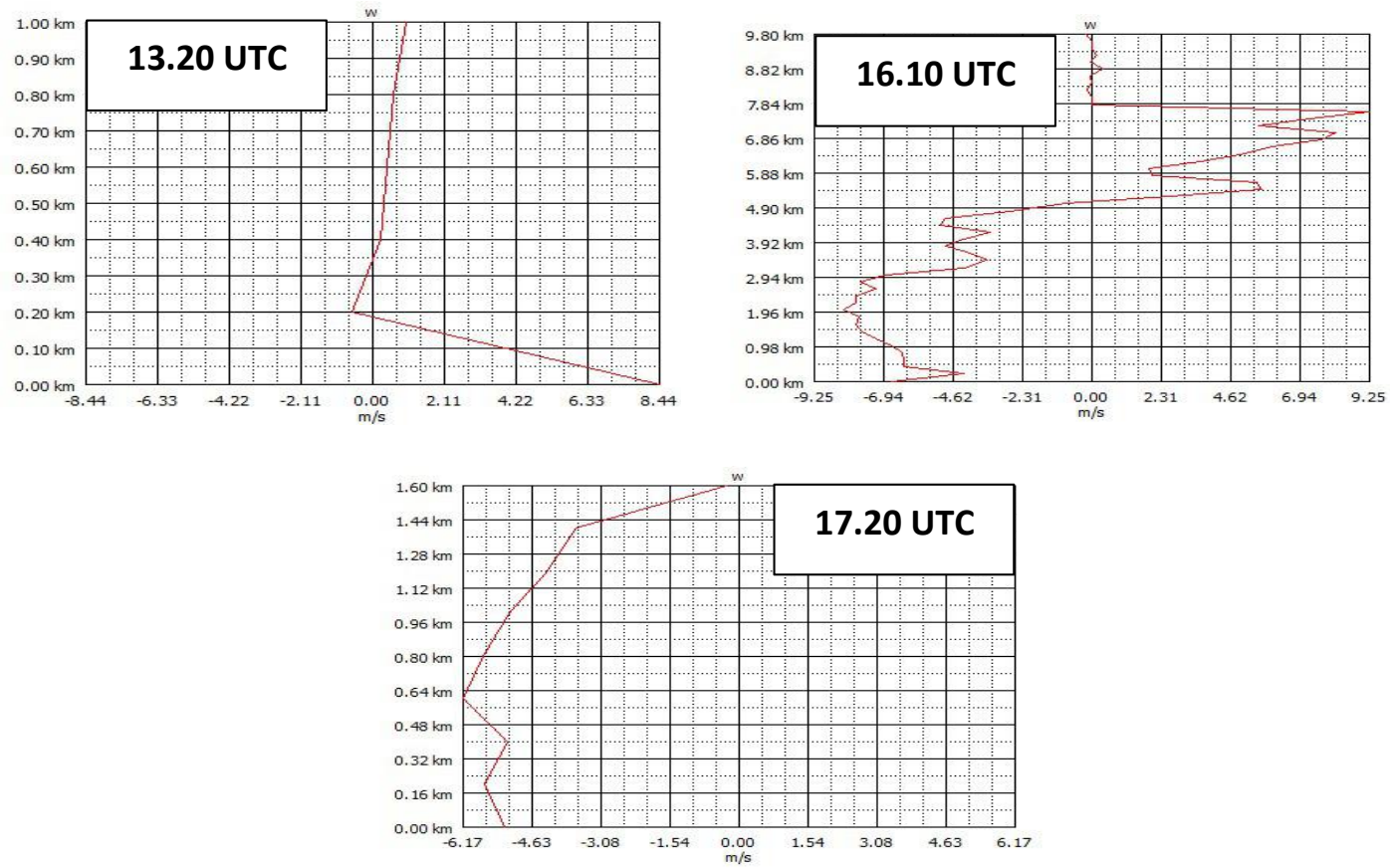

Gambar 3. Analisis kecepatan vertikal pada struktur awan badai. Nilai positif menunjukkan terjadinya updraft dan nilai negatif menunjukkan terjadinya downdraft.

\subsection{Identifikasi Curah Hujan dengan Produk SRI}

Instruksi manual produk Rainbow 5 menjelaskan bahwa produk SRI menghasilkan informasi terkait intensitas curah hujan (rain rate) pada lapisan permukaan yang dipilih oleh pengguna dengan ketinggian tetap di atas permukaan tanah (SELEX module). Produk ini penting untuk dianalisis sebagai data masukan untuk produk rain tracking (RTR) yang akan digunakan selanjutnya dalam penelitian ini. Menurut Wardoyo, produk SRI merupakan salah satu produk utama yang penting digunakan untuk analisis kejadian banjir. ${ }^{12}$ Penelitian yang dilakukan oleh Widomurti menunjukkan bahwa SRI merupakan produk terbaik untuk estimasi curah hujan dan sangat baik untuk wilayah yang dekat dengan pusat radar (Widomurti, 2017). Lebih lanjut, penelitian Kusjantho menunjukkan bahwa produk SRI memiliki performa yang lebih baik dalam menangkap pola curah hujan dalam periode singkat (Kusjantho, 2018).

Analisis produk SRI dengan menggunakan algoritma Rosenfeld Tropical dilakukan selama rentang waktu 14.00 - 17.00 UTC (Gambar 4), dimana hujan akibat awan konvektif terjadi. Analisis produk SRI pada pukul 18.00 UTC tidak dilakukan karena hasil pengamatan sinoptik dan CAPPI menunjukkan tidak diamatinya awan-awan kovektif pada waktu tersebut. Pada pukul 14.00 UTC, intensitas curah hujan di lokasi penelitian menunjukkan nilai sebesar $23,87 \mathrm{~mm} / \mathrm{jam}$. Pada pukul 15.00 UTC, intensitas tersebut cenderung mengalami penurunan, yaitu menjadi $6,72 \mathrm{~mm} / \mathrm{jam}$. 
Intensitas curah hujan mengalami kenaikan yang signifikan pada pukul 16.00 UTC, dimana intensitasnya mencapai $55,62 \mathrm{~mm} / \mathrm{jam}$.

\subsection{Prediksi Intensitas Curah Hujan dan Persebarannya}

Instruksi manual produk Rainbow 5 (2018) menjelaskan bahwa produk RTR dapat digunakan untuk memantau pergerakan dan memprakirakan posisi medan curah hujan dalam waktu dekat (near future/nowcasting). Dalam penelitian ini, input produk yang digunakan untuk mengolah data RTR adalah produk SRI dengan algoritma Rosenfeld Tropical. Waktu prakiraan (forecast time) yang digunakan adalah 20 menit, artinya citra radar
Sementara pada pukul 17.00 UTC, intensitas curah hujan kembali mengalami penurunan menjadi $8,74 \mathrm{~mm} / \mathrm{jam}$.

pada pukul 13.40 UTC digunakan untuk memprediksi intensitas dan sebaran medan curah hujan pada pukul 14.00 UTC, citra radar pukul 14.40 UTC digunakan untuk memprediksi intensitas dan sebaran medan curah hujan pada pukul 15.00 UTC, dan seterusnya. Dalam penelitian ini, produk SRI digunakan sebagai pembanding karena beberapa penelitian menunjukkan bahwa

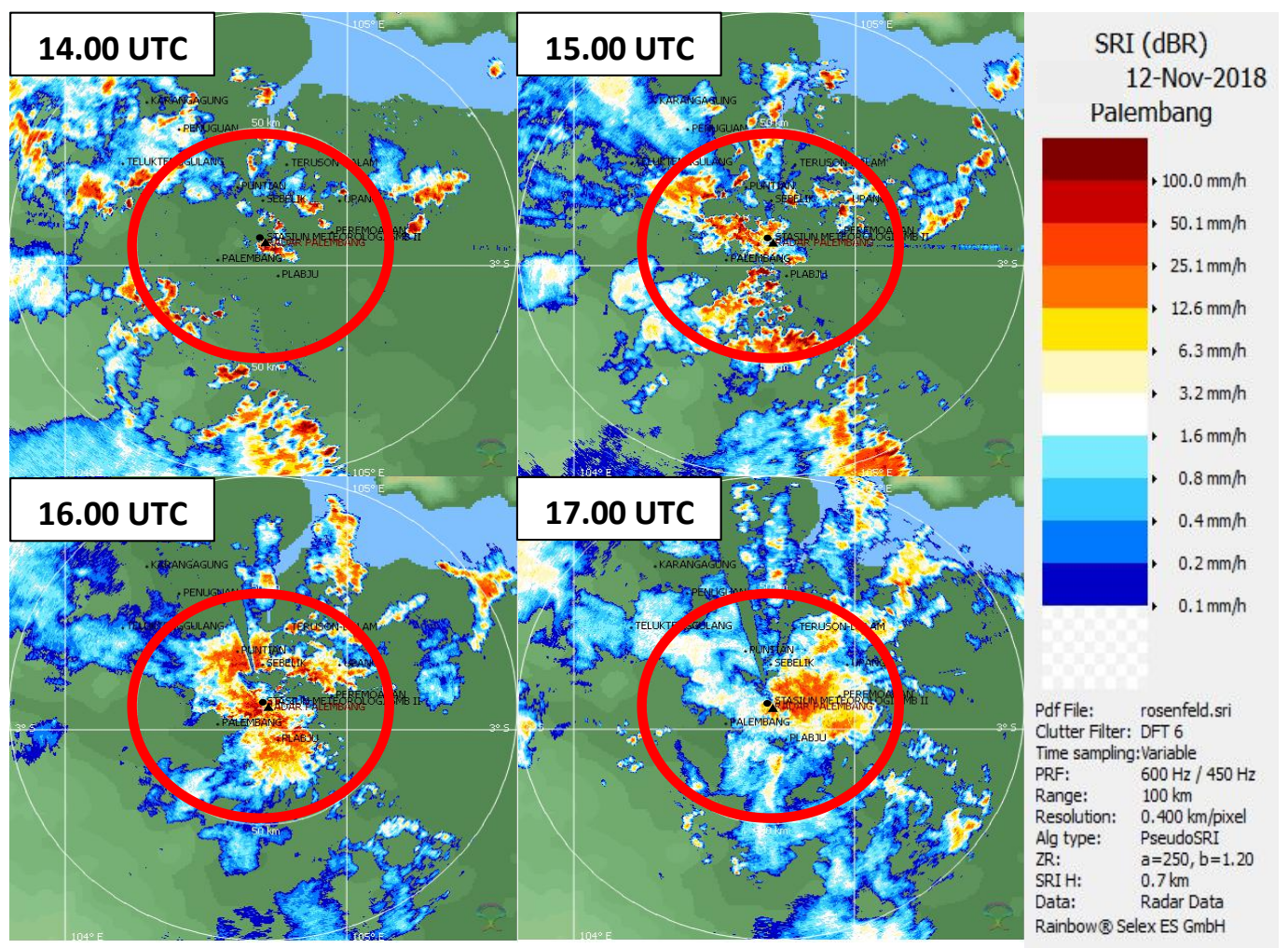

Gambar 4. Sebaran spasial intensitas curah hujan berdasarkan produk SRI dengan algoritma Rosenfeld Tropical. Lingkaran merah menunjukkan sebaran curah hujan di lokasi penelitian dan wilayah sekitar radar cuaca, symbol segitiga hitam menunjukkan posisi radar cuaca, sementara simbol lingkaran hitam menunjukkan lokasi penelitian, yaitu Stasiun Meteorologi Sultan Mahmud Badaruddin II.

produk SRI merupakan produk hidrologi paling baik untuk estimasi intensitas curah hujan. ${ }^{10,18}$ Secara umum, hasil penelitian menunjukkan bahwa semakin pendek interval waktu antara produk SRI dan produk RTR, maka hasil prediksi curah hujan di lokasi penelitian cenderung menunjukkan hasil yang mendekati kondisi sebenarnya. Hasil prediksi intensitas dan persebaran medan curah hujan ditunjukkan melalui Gambar 6, sementara perbandingan curah hujan pada produk SRI, RTR, dan pengukuran curah hujan sebenarnya menggunakan ARG ditunjukkan pada Tabel 5 dan 6.

Tabel 5. Perbandingan intensitas curah hujan hasil pengamatan ARG di Stasiun Meteorologi Sultan Mahmud Badaruddin II dan produk SRI 


\begin{tabular}{|c|l|c|c|c|c|}
\hline \multirow{2}{*}{ No } & \multirow{2}{*}{ Skema Pengamatan } & \multicolumn{4}{|c|}{ Intensitas Curah Hujan (mm/jam) } \\
\cline { 3 - 6 } & & $\mathbf{1 4 . 0 0}$ UTC & $\mathbf{1 5 . 0 0}$ UTC & $\mathbf{1 6 . 0 0}$ UTC & $\mathbf{1 7 . 0 0}$ UTC \\
\hline 1 & $\begin{array}{l}\text { Pengamatan curah hujan } \\
\text { dengan ARG }\end{array}$ & 48,4 & 5,8 & 39,6 & 6,6 \\
\hline 2 & $\begin{array}{l}\text { Pengamatan curah hujan } \\
\text { dengan produk SRI }\end{array}$ & 23,87 & 6,72 & 55,62 & 8,74 \\
\hline \multicolumn{2}{|l}{ Selisih (SRI-ARG) } & $-24,53$ & $+0,92$ & $+16,02$ & $+2,14$ \\
\hline
\end{tabular}

Tabel 6. Perbandingan intensitas curah hujan hasil pengamatan ARG di Stasiun Meteorologi Sultan Mahmud Badaruddin II dan produk RTR

\begin{tabular}{|c|l|c|c|c|c|}
\hline \multirow{2}{*}{ No } & \multirow{2}{*}{ Skema Pengamatan } & \multicolumn{4}{|c|}{ Intensitas Curah Hujan (mm/jam) } \\
\cline { 3 - 6 } & $\mathbf{1 4 . 0 0}$ UTC & $\mathbf{1 5 . 0 0}$ UTC & $\mathbf{1 6 . 0 0}$ UTC & $\mathbf{1 7 . 0 0}$ UTC \\
\hline 1 & $\begin{array}{l}\text { Pengamatan curah hujan } \\
\text { dengan ARG }\end{array}$ & 48,4 & 5,8 & 39,6 & 6,6 \\
\hline 2 & $\begin{array}{l}\text { Prakiraan curah hujan } \\
\text { dengan produk RTR }\end{array}$ & 52,55 & 7,65 & 24,84 & 7,84 \\
\hline \multicolumn{2}{|c|}{ Selisih (RTR-ARG) } & $+4,15$ & $+1,85$ & $-14,76$ & $+1,24$ \\
\hline
\end{tabular}

Intensitas curah hujan pada produk RTR pada pukul 14.00 - 14.59 UTC diperkirakan mencapai $52,55 \mathrm{~mm} / \mathrm{jam}$. Hasil pengamatan curah hujan menggunakan ARG di Stasiun Meteorologi Sultan Mahmud Badaruddin II menunjukkan nilai yang sedikit lebih rendah, yaitu $48,4 \mathrm{~mm} / \mathrm{jam}$, sehingga selisih nilai intensitas curah hujan dengan produk RTR adalah sekitar $4,15 \mathrm{~mm} / \mathrm{jam}$. Sementara itu, intensitas curah hujan yang ditunjukkan produk SRI pada waktu yang sama menunjukkan nilai 23,87 $\mathrm{mm} / \mathrm{jam}$ sehingga cenderung underestimate jika dibandingkan dengan nilai intensitas curah hujan ARG dengan selisih nilai sekitar 24,53 $\mathrm{mm} / \mathrm{jam}$. Pada pukul 15.00 15.59 UTC, intensitas curah hujan yang diamati menggunakan RTR diperkirakan mencapai 7,65 $\mathrm{mm} / \mathrm{jam}$. Nilai intensitas tersebut relatif overestimate jika dibandingkan hasil pengamatan curah hujan dengan ARG yang menunjukkan nilai sekitar $5,8 \mathrm{~mm} / \mathrm{jam}$. Analisis produk SRI menunjukkan nilai yang lebih mendekati nilai intensitas curah hujan ARG, yaitu sekitar $6,72 \mathrm{~mm} / \mathrm{jam}$. Berdasarkan analisis tersebut, dapat diketahui bahwa selisih nilai absolut intensitas curah hujan antara produk RTR dan ARG adalah sekitar $1,85 \mathrm{~mm} / \mathrm{jam}$, sementara selisih nilai curah hujan antara produk SRI dan ARG cenderung lebih kecil, yaitu $0,92 \mathrm{~mm} / \mathrm{jam}$. Pada pukul $16.00-16.59$ UTC, intensitas curah hujan pada produk RTR diperkirakan meningkat signifikan, yaitu mencapai $24,84 \mathrm{~mm} / \mathrm{jam}$. Analisis produk SRI pada waktu yang sama menunjukkan nilai intensitas curah hujan sebesar 55,62 mm/jam. Sementara itu, analisis curah hujan menggunakan ARG menunjukkan nilai 39,6 $\mathrm{mm} / \mathrm{jam}$, artinya selisih nilai absolut intensitas curah hujan sebenarnya dengan produk RTR relatif lebih kecil, yaitu sekitar $14,76 \mathrm{~mm} / \mathrm{jam}$. Sementara itu, selisih nilai absolut intensitas curah hujan antara produk ARG dan SRI relatif lebih besar, yaitu $16,02 \mathrm{~mm} / \mathrm{jam}$. Pada pukul $17.00-17.59$ UTC, intensitas curah hujan yang diamati dengan menggunakan ARG menunjukkan nilai $6,6 \mathrm{~mm} / \mathrm{jam}$. Prediksi intensitas curah hujan menggunakan RTR menunjukkan nilai yang cenderung overestimate, yaitu $7,84 \mathrm{~mm} / \mathrm{jam}$. Hal yang sama juga ditunjukkan oleh nilai intensitas curah hujan pada produk SRI yang cenderung overestimate jika dibandingkan hasil pengamatan intensitas curah hujan dengan ARG, yaitu $8,74 \mathrm{~mm} / \mathrm{jam}$.

Berdasarkan analisis yang dilakukan, produk SRI kurang baik dalam menyediakan informasi intensitas curah hujan dengan intensitas tinggi, sehingga umumnya selisih nilai intensitas curah hujan dengan produk ARG akan semakin besar (galat semakin besar). Apabila intensitas curah hujan relatif ringan, selisih nilai curah hujan antara produk SRI dan pengamatan curah hujan sebenarnya menggunakan ARG relatif lebih kecil (galat semakin kecil). Secara umum, nilai absolut selisih intensitas curah hujan produk 
SRI dengan hasil pengamatan curah hujan sebenarnya dengan ARG di lokasi penelitian berkisar antara $0,92-24,53 \mathrm{~mm} / \mathrm{jam}$. Sementara itu, hasil prediksi intensitas curah hujan dengan menggunakan produk RTR cenderung menunjukkan nilai yang lebih mendekati hasil pengamatan intensitas curah hujan menggunakan ARG. Secara umum, produk RTR lebih baik dalam merepresentasikan intensitas curah hujan, baik ringan, sedang, atau berat, di lokasi penelitian dengan selisih nilai absolut intensitas curah hujan berkisar antara 1,24 - 14,76 mm/jam. Namun jika dibandingkan dengan SRI, produk RTR dalam penelitian ini menunjukkan pola sebaran spasial medan curah hujan yang cukup berbeda pada skala waktu yang sama, utamanya pada daerah yang letaknya jauh dari pusat radar.

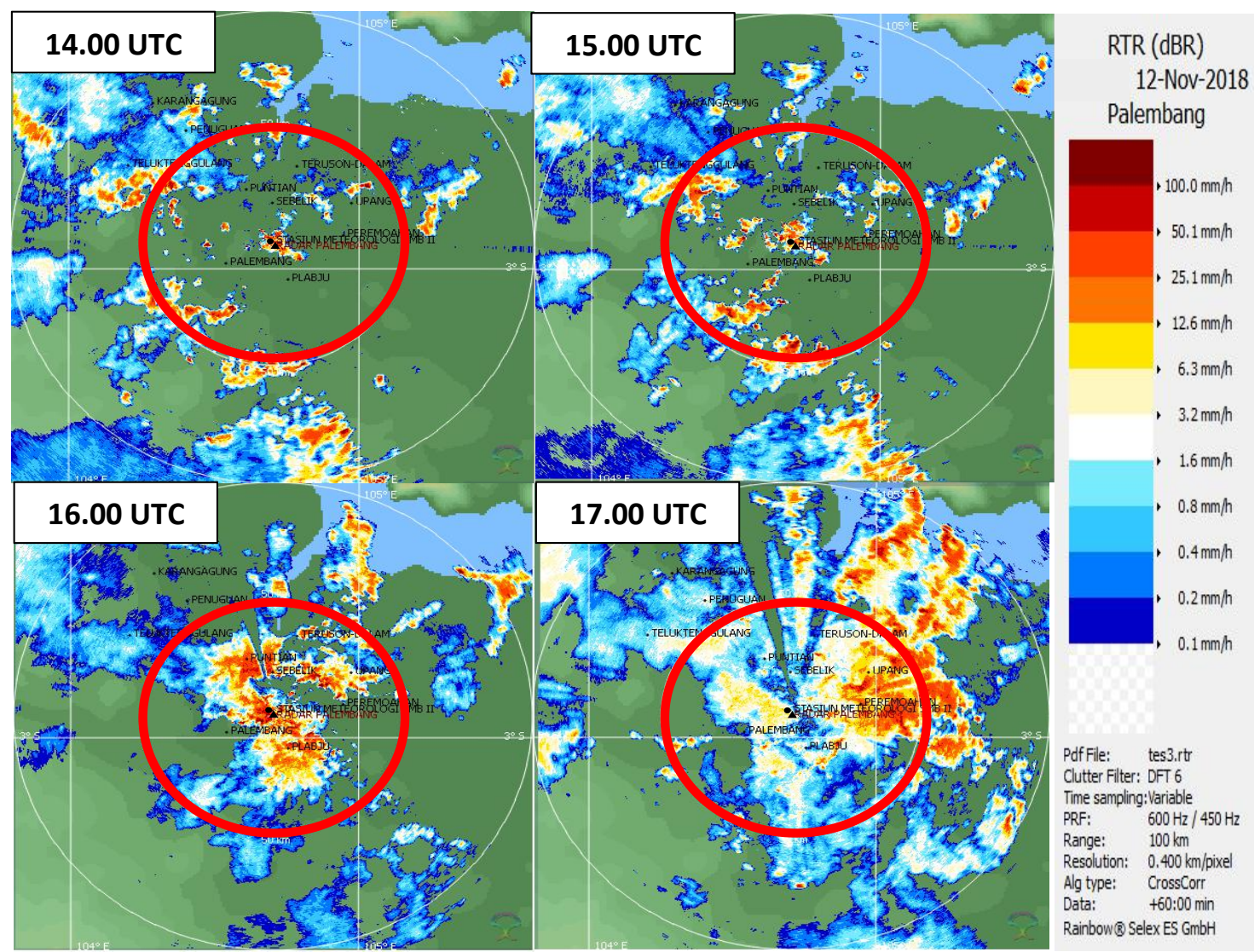

Gambar 5. Hasil prediksi intensitas dan sebaran medan curah hujan RTR dengan input produk SRI untuk prediksi pukul 14.00 - 17.00 UTC. Lingkaran merah menunjukkan sebaran curah hujan di lokasi penelitian dan wilayah sekitar radar cuaca, simbol segitiga hitam menunjukkan posisi radar cuaca, sementara simbol lingkaran hitam menunjukkan lokasi penelitian, yaitu Stasiun Meteorologi Sultan Mahmud Badaruddin II.

\section{KESIMPULAN}

Di bawah skenario perubahan iklim global, kejadian banjir memiliki kecenderungan untuk terus meningkat seiring waktu, utamanya di beberapa wilayah rawan banjir seperti di wilayah Palembang. Pada umumnya, penelitian-penelitian terkait dengan kejadian banjir memanfaatkan radar cuaca sebagai alat untuk menganalisis objek awan penyebab kejadian banjir. Seiring dengan perkembangan teknologi penginderaan jarak jauh dan peningkatan resolusi spasial dan temporal data radar cuaca, penelitian ini memanfaatkan produk nowcasting radar cuaca, yaitu RTR untuk memprediksi intensitas curah hujan yang akan terjadi. Hasil prediksi intensitas curah hujan dengan produk RTR kemudian dibandingkan dengan hasil estimasi curah hujan dengan produk SRI dan pengukuran langsung dengan ARG untuk mengetahui performa produk RTR di wilayah penelitian. Secara umum, pada saat terjadi hujan dengan intensitas ringan hingga sedang, produk SRI mampu menunjukkan intensitas curah hujan yang mendekati nilai curah hujan sebenarnya berdasarkan pengamatan curah hujan dengan ARG. Namun pada saat hujan terjadi dengan intensitas tinggi, produk SRI cenderung 
menunjukkan penyimpangan nilai yang besar dibandingkan dengan pengukuran nilai intensitas curah hujan ARG. Sebaliknya, prakiraan curah hujan dengan menggunakan produk RTR cenderung menunjukkan nilai yang relatif lebih stabil dan mendekati nilai pengamatan curah hujan ARG dengan nilai absolut perbedaan intensitasnya berkisar antara $1,24-14,76 \mathrm{~mm} / \mathrm{jam}$. Namun jika dibandingkan dengan SRI, produk RTR dalam penelitian ini menunjukkan pola sebaran spasial medan curah hujan yang cukup berbeda pada skala waktu yang sama, utamanya pada daerah yang letaknya jauh dari pusat radar. Penelitian lebih lanjut diperlukan untuk dapat menentukan produk radar terbaik yang lebih mampu merepresentasikan sebaran spasial medan curah hujan sebenarnya di Palembang.

\section{DAFTAR PUSTAKA}

IPCC. 2007. Climate Change 2007: The Physical Science Basis. Contribution of Working Group I to the Fourth Assessment Report of the Intergovernmental Panel on Climate Change [Solomon, S., D. Qin, M. Manning, Z. Chen, M. Marquis, K.B. Averyt, M. Tignor, H.L. Miller (eds.)]. Cambridge University Press, Cambridge, United Kingdom and New York, NY, USA.

Lassa, J. A. 2012. Emerging 'Agricultural Involution' in Indonesia: Impact of Natural Hazards and Climate Extremes on Agricultural Crops and Food System. In Y. Sawada and S. Oum, eds. Economic and Welfare Impacts of Disasters in East Asia and Policy Responses. ERIA Research Project Report 2011-8. Jakarta: ERIA. pp. 601-640.

Triansyah, Y. 2018. Diguyur Hujan Semalaman, Ini 19 Titik Banjir di Kota Palembang dan 5 Titik Paling Parah [online]. http://palembang.tribunnews.com/2018/11/1 3/diguyur-hujan-semalaman-ini-19-titikbanjir-di-kota-palembang-dan-5-tempatpaling-parah, diakses tanggal 7 Desember 2018.

James, W., Robinson, C. G., Bell, J. F. 1993. Radar assisted real - time flood forecasting. $J$. of Water Resour. Plannn. and Management, 119(1): 32 - 44.

Paski, J. A. I., Budi, F. S., Pertiwi, D. A. S. 2016. Analisis dinamika atmosfer kejadian hujan ekstrim memanfaatkan citra radar, satelit, dan model WRF. Jurnal Meteorologi Klimatologi dan Geofisika, 2(2): 251 - 261.

Permana, P. A. D. dan Fachrurrozi, M. 2016. Pemanfaatan Data Radar Cuaca untuk Analisis Kejadian Banjir di Wilayah Kediri, NTB (Studi kasus 2 Mei 2015). Prosiding Seminar Hari Meteorologi Dunia, pp. $309-$ 315, ISBN: 978-602-60274-3-6.

Ariyanti, D. A., Asmarani, D., Sa'adah, U. 2016. Identifikasi Awan Cumulonimbus dengan Citra Radar Cuaca Saat Hujan Lebat di Jakarta (Studi kasus tanggal 20 April 2016). Prosiding Seminar Nasional Penginderaan Jauh, pp. 988 - 997, ISBN: 978-979-1458-99-3.

Rosenfeld, D., B. Wolff, D.p Atlas. 1993. General probability-matched relationship between radar reflectivity and rain rate. $J$. App. Meteor., 32, 50 - 72.

Gamache, J.F. dan Houze Jr., R.A. 1982. Mesoscale air motions associated with a tropical squall line. American Meteorologi Society, vol. 110, pp 118-135.

Widomurti, L. 2017. Penentuan rentang Video Integrator Processor (VIP) level curah hujan berdasar klasifikasi awan pada pengamatan radar cuaca. Skripsi. Tangerang Selatan: Sekolah Tinggi Meteorologi Klimatologi dan Geofisika.

Nzeukou, A. dan Sauvageot, H. 2004. Raindrop size distribution and radar parameters at Cape Verde. J. of Applied Meteorology, vol. 43, pp 90-105.

Wardoyo, E. 2017. Radar Meteorologi: Pengantar Aplikasi Meteorologi. Badan Meteorologi Klimatologi dan Geofisika. Jakarta.

Szoke E J, C K Mueller, J W Wilson, E J Zipser. 1985. Development of convection and severe weather along outflow boundaries in Northeast Colorado: Diagnosing the abovesurface environment with a mobile sounding system. Preprints, 14th Conf. on Severe Local storms, Indianapolis Amer. Meteor. Soc. 386-89.

Kollias, P., Albrecth, B. A., Lhermite, R., Savtchenko, A. 2001. Radar observation of updraft, downdraft, and turbulence in fairweather cumuli. $J$. of the atmospheric sciences, vol. 58 pp. $1750-1766$.

Byers, H. R. dan Hull, E. C. 1949. Inflow patterns of thunderstorm as shown by winds alofts. Bulletin American Meteorological Society, 30(3): 90 - 96. 
Byers, H. R. dan Braham, R. R. 1949. The thunderstorm. U.S. Dept. of Commerce, 287 pp.

SELEX, Gematronik. 2018. Software Manual Rainbow 5: Products \&Algorithms. Jerman: Leonardo Germany $\mathrm{GmbH}$.

Kusjantho, A. 2018. Verifikasi Produk Hidrologi Radar Cuaca Gematronik untuk Estimasi Curah Hujan di Wilayah Lombok Periode Oktober - Desember 2016. Skripsi. Tangerang Selatan: Sekolah Tinggi Meteorologi Klimatologi dan Geofisika. 